\title{
DETEKSI Escherichia coli PATOGEN PADA PANGAN MENGGUNAKAN METODE KONVENSIONAL DAN METODE MULTIPLEX PCR
}

\author{
Evy Ratnasari Ekawati ${ }^{1)}$, Siti Nur Husnul Y. ${ }^{2)}$, Fakhmi Rooslan Hamidi ${ }^{2)}$ \\ ${ }^{1), 2}$ Dosen Fakultas Ilmu Kesehatan, Universitas Maarif Hasyim Latif Sidoarjo \\ ${ }^{3)}$ Balai Besar POM di Surabaya \\ evysains@dosen.umaha.ac.id
}

\begin{abstract}
Foodstuffs are a source of nutrition for humans and as well as a source of food for microorganisms. Microbes can contaminate food through water, dust, air, soil, processing tools (during production or preparation processes, as well as secretions from human and animal guts). Food can be toxic because it has been contaminated by pathogenic bacteria which can then grow and multiply during storage, so the bacteria are able to produce toxins that are harmful to humans. The aimed of this study was to detect the presence of Escherichia coli pathogen in food. This type of research is experimental laboratory using conventional method and multiplex PCR method. 8 positive samples of Escherichia coli ATCC 25922 by conventional method, consisting of 5 samples of tofu; 2 samples of ice syrup and 1 sample iced tea. All positive samples in EMB agar continued Escherichia coli pathogen detection using PCR multiplex method. From the PCR multiplex test, no samples were detected Escherichia coli pathogen
\end{abstract}

Keywords: Escherichia coli, foodstuffs, conventional method, multiplex PCR method

\section{PENDAHULUAN}

Pangan adalah segala sesuatu yang berasal dari sumber hayatu dan air, baik yang diolah maupun tidak diolah, yang diperuntukkan sebagai makanan atau minuman bagi konsumsi manusia termasuk bahan tambahan pangan, bahan baku pangan dan bahan lain yang digunakan dalam proses penyiapan, pengolahan dan atau pembuatan makanan atau minuman. Definisi pangan yang memiliki cakupan luas, maka upaya untuk mencegah pangan dari kemungkinan tercemar, baik dari cemaran biologis, kimia dan benda lain yang dapat mengganggu, merugikan dan membahayakan kesehatan manusia merupakan suatu keharusan (UU RI No. 7, 1996; BPOM, 2008).

Bahan makanan merupakan sumber gizi bagi manusia dan sekaligus sebagai sumber makanan bagi mikroorganisme. Pertumbuhan mikroorganisme dalam bahan pangan dapat menyebabkan perubahan yang menguntngkan, seperti perbaikan bahan pangan secara gizi, daya cerna amaupun daya simpannya. Tetapi pertumbuhan mikroorganisme dalam bahan pangan juga dapat mengakibatkan perubahan fisik atau kimia yang tidak diinginkan, sehingga bahan pangan tersebut menjadi tidak layak untuk dikonsumsi. Hal tersebut terjadi pada prmbusukan bahan pangan (Siagian, 2002).

Mikroba dapat mencemari pangan melalui air, debu, udara, tanah, alat-alat pengolah (selama proses produksi atau penyiapan) juga sekresi dari usus manusia dan hewan. Penyakit akibat pangan (food borne disease) yang terjadi segera setelah mengkonsumsi pangan, umumnya disebut dengan keracunan. Pangan dapat beracun karena telah terkontaminasi oleh bakteri pathogen yang kemudian dapat tumbuh dan berkembang biak selama penyimpanan, sehingga bakteri tersebut mampu memproduksi 
toksin yang berbahaya bagi manusia. Bakteri yang terkait dengan keracunan makanan diantaranya adalah Escherichia coli enteropatogenik, Salmonella, Shigella, Campylobacter, Listeria monocytogenes, Yersinia enterocolityca, Staphylococcus aureus, Clostridium perfringens, Clostridium botulinum, Bacillus cereus, Vibrio cholera, Vibrio parahaemolyticus dan Enterobacter sakazaki (ISO, 2006; BPOM, 2008).

Data BPOM berdasarkan laporan balai besar/balai POM mengenai frekuensi kejadian luar biasa (KLB) keracunan pangan pada 25 propinsi, melaporkan frekuensi kejadian luar biasa (KLB) keracunan pangan pada 3 kota diantaranya kota Semarang terdapat 14 kejadian (10,94\%), Makassar dengan 14 kejadian (10,94\%) dan Lampung dengan 12 kejadian $(9,38 \%)$. Berdasarkan tempat atau lokasi kejadian KLB keracunan pangan pada 19 tempat, Sekolah Dasar (SD) menempati urutan kedua tempat KLB dengan angka kejadian 24 kejadian $(18,75 \%)$ setelah tempat atau lokasi rumah tangga dengan 59 kejadian $(46,09 \%)$, disusul pada urutan ketiga, yaitu tempat terbuka dengan 8 kejadian (6,25\%) (BPOM, 2011).

Bahaya mikroba pada pangan perlu mendapat perhatian, karena jenis bahaya ini sering menjadi agen penyebab kasus keracunan pangan. Escherichia coli merupakan bakteri pathogen yang sering menyebabkan keracunan pangan dan juga menjadi salah satu mikroba inidikator sanitasi. Keberadaan Escherichia coli pada pangan dapat menunjukkan bahwa prakten sanitasi lingkungan yang buruk (Wijaya, 2009). Escherichia coli umumnya berhabitat pada saluran pencernaan manusia dan hewan (Tannock, 1995; Sorum and Sunde, 2001; Biswas, 2010), dapat dengan mudah disebarluaskan di luar habitat asalnya melaui perantara air dan pangan (Perreten, 2005). Pada kondisi tertentu, Escherichia coli dapat menyebabkan infeksi, terutama pada pasien dengan gangguan sistem imun atau pada kondisi dimana barrier pada gastrointestinal terganggu, bahkan Escherichia coli non pathogen sekalipun dapat menyebabkan infeksi (Huang et al., 2006).

Sekitar 98\% mikroba yang terdapat pada pangan merupakan mikroba non pathogen (Kumar et al., 2002). Sehingga perlu dikembangkan tes diagnostik yang sesuai untuk mendeteksi Escherichia coli pathogen. Metode konvensional untuk mendeteksi bakteri pathogen pada pangan adalah dengan teknik kultur (Djoepri, 2006; Biswas et al., 2010). Karakterisasi fenotip dan genotip membutuhkan waktu 3-4 hari untuk memastikan hasilnya. Deteksi dengan imunologi dan biokimia memakan waktu, membutuhkan kultur murni dan kurang sensitif terhadap metode molekuler.Metode berbasis DNA dapat digunakan dengan menggunakan kultur bakteri campuran. Variasi polimorfisme DNA diantara berbagai spesies bakteri dapat dieksploitasi untuk mengidentifikasi pathogen pada pangan (Biswas et al., 2010).

Berdasarkan uraian tersebut, peneliti melakukan kajian adanya Escherichia coli pathogen dalam berbagai jenis sampel pangan yang dikumpulkan dari pasar tradisional, ritel modern dan penjual di sekitar sekolah dasar.

\section{METODOLOGI PENELITIAN}

Jenis penelitian ini adalah eksperimental laboratorium. Pengambilan sampel dilakukan sesuai dengan protokol sampling yang telah disusun, yaitu pengambilan sampel rutin dan pengambilan sampel khusus untuk kajian ini. Ruang lingkup protokol ini adalah persiapan pengambilan dan penanganan sampel yang diambil untuk dianalisis mikrobiologi terkait keberadaan Escherechia coli pathogen. Sampel yang dianalisis merupakan sampel pangan yang berasal dari beberapa sub katergori pangan.

\section{Waktu dan Tempat Penelitian}

Pengambilan sampel dilakukan pada bulan Juni - Agustus 2016 di 22 lokasi, yaitu 6 pasar tradisional, 4 ritel modern, dan 12 SD/MI yang tersebar di Kota Surabaya, Provinsi Jawa Timur. Lokasi sampling merupakan lokasi 
pengambilan sampel rutin yang dilakukan oleh Balai Besar POM di Surabaya dan untuk SD/MI yang menjadi lokasi sampling PJAS adalah sekolah dengan temuan Escherichia coli pada PJAS dalam sampling tahun-tahun sebelumnya. sedangkan deteksi keberadaan dan jenis Escherichia coli pathogen dilakukan bulan Juni-Oktober 2016.

\section{Pengujian Mikrobiologi}

\section{1) Metode Konvensional}

Pengujian mikrobiologi dilakukan untuk deteksi keberadaan Escherichia coli pathogen pada sampel pangan yang diambil. Parameter analisis yang digunakan yaitu :Escherichia coli secara kuantitatif dengan metode APM Escherichia coli. Standar cemaran mikrobiologi Escherichia coli pada pangan yang digunakan sebagai acuan adalah peraturan Kepala Badan Pengawas Obat dan Makanan No. HK.00.06.1.52.4011

\section{Bagan Pengujian Deteksi Escherichia coli Patogen}
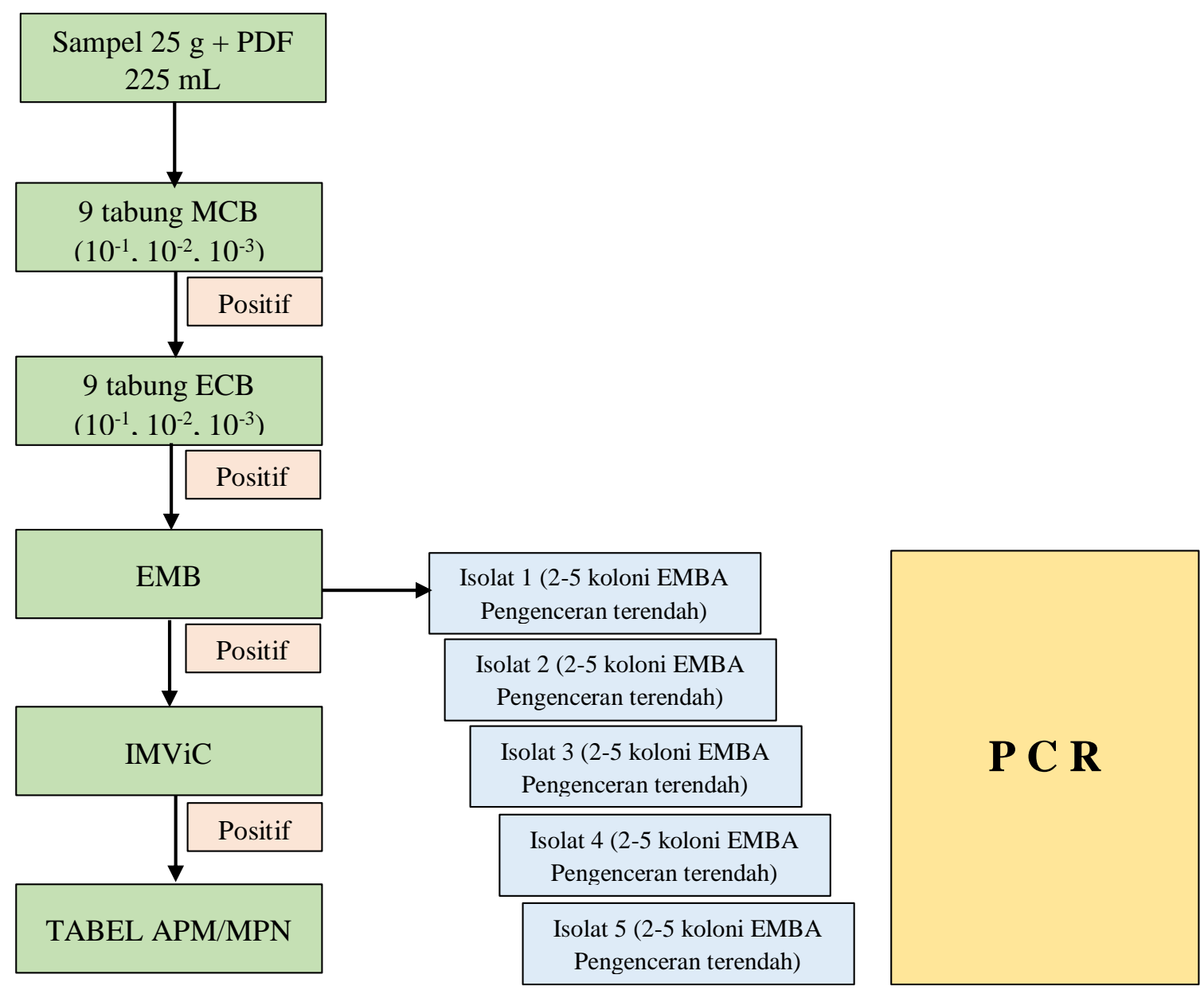


\section{HASIL DAN PEMBAHASAN}

\section{Identifikasi Escherichia coli pada Sampel Pangan}

Dari seluruh pengambilan sampel telah dilakukan uji Deteksi Escherichia coli dengan menggunakan metode konvensional dan metode multiplex PCR untuk deteksi Escherichia coli patogen. Sesuai dengan protokol uji yang tersedia. Uji Deteksi Escherichia coli pathogen dilakukan apabila terdapat koloni tipikal pada media EMB Agar, dilakukan uji parallel terhadap sampel tersebut baik secara konvensional maupun PCR.

Setelah dilakukan pengujian sampel dari bulan Juni-Oktober 2016, didapatkan hasil bahwa 8 sampel positif Escherichia coli ATCC
25922 secara metode konvensional, yang terdiri dari 5 sampel tahu; 2 sampel es sirup dan 1 sampel es teh. Seluruh sampel yang positif di EMB Agar dilanjutkan deteksi Escherichia coli pathogen dengan menggunakan metode multiplex PCR. Dari uji multiplex PCR, tidak ada satu sampel pun yang terdeteksi Escherichia coli pathogen. Data hasil pengujian disajikan pada Tabel 1.

Tabel 1 Hasil Pengujian Escherichia coli Patogen pada Pangan

\begin{tabular}{|c|c|c|c|c|c|c|c|c|}
\hline \multirow{3}{*}{ No } & \multirow{3}{*}{ Jenis Sampel } & \multirow{3}{*}{$\mathbf{N}$} & \multirow{3}{*}{ Standar } & \multirow{3}{*}{$\begin{array}{c}\text { Nilai APM } \\
\text { Rata-rata } \\
\text { (APM/g) }\end{array}$} & \multicolumn{4}{|c|}{$\begin{array}{c}\text { Persentase Temuan Escherichia coli } \\
\text { Patogen }(\%)\end{array}$} \\
\hline & & & & & \multirow{2}{*}{$\begin{array}{c}\text { Metode } \\
\text { Konvensional }\end{array}$} & \multicolumn{3}{|c|}{ Metode Multiplex PCR } \\
\hline & & & & & & ETEC & EPEC & EHEC \\
\hline 1 & Tepung terigu & 8 & $<3$ APM/g & 0 & 0 & 0 & 0 & 0 \\
\hline 2 & Mi basah mentah & 8 & $<3 \mathrm{APM} / \mathrm{g}$ & 0 & 0 & 0 & 0 & 0 \\
\hline 3 & Tahu & 8 & $<3$ APM/g & $>1100$ & 62,5 & 0 & 0 & 0 \\
\hline 4 & Biskuit & 4 & $<3 \mathrm{APM} / \mathrm{g}$ & 0 & 0 & 0 & 0 & 0 \\
\hline 5 & Keik & 4 & $<3 \mathrm{APM} / \mathrm{g}$ & 0 & 0 & 0 & 0 & 0 \\
\hline 6 & Sosis ayam & 4 & $<3$ APM/g & 0 & 0 & 0 & 0 & 0 \\
\hline 7 & Sosis sapi & 4 & $<3 \mathrm{APM} / \mathrm{g}$ & 0 & 0 & 0 & 0 & 0 \\
\hline 8 & Dendeng daging & 8 & $<3 \mathrm{APM} / \mathrm{g}$ & 0 & 0 & 0 & 0 & 0 \\
\hline 9 & Bakso daging & 8 & $<3 \mathrm{APM} / \mathrm{g}$ & 0 & 0 & 0 & 0 & 0 \\
\hline 10 & Bakso ikan & 4 & $<3 \mathrm{APM} / \mathrm{g}$ & 0 & 0 & 0 & 0 & 0 \\
\hline 11 & Otak-otak ikan & 4 & $<3 \mathrm{APM} / \mathrm{g}$ & 0 & 0 & 0 & 0 & 0 \\
\hline 12 & Agar-agar & 9 & $<3 \mathrm{APM} / \mathrm{g}$ & 0 & 0 & 0 & 0 & 0 \\
\hline 13 & Es The & 9 & $<3 \mathrm{APM} / \mathrm{g}$ & 21 & 11,11 & 0 & 0 & 0 \\
\hline 14 & Es Sirup & 9 & $<3 \mathrm{APM} / \mathrm{g}$ & 131 & 22,22 & 0 & 0 & 0 \\
\hline 15 & Bakso pentol & 9 & $<3 \mathrm{APM} / \mathrm{g}$ & 0 & 0 & 0 & 0 & 0 \\
\hline
\end{tabular}

Hasil Pengujian Escherichia coli Patogen pada Pangan Berdasarkan Jenis Registrasi

Dari 8 sampel yang positif Escherechia coli ATCC 25922, berdasarkan jenis registrasinya paling banyak adalah untuk 5 sampel tahu dengan registrasi PIRT, 2 sampel es sirup dan 1 sampel es teh yang memang tanpa registrasi. Hasil pengujian Escheriachia coli pathogen berdasarkan jenis registrasi disajikan pada Tabel 2.

\section{Hasil Pengujian Escherichia coli Pada Pangan Berdasarkan Lokasi}

Pengambilan sampel pada kajian ini dilakukan pada bulan Juni-September 2016 di 22 lokasi, yaitu 6 pasar tradisional, 4 ritel modern dan di 12 SD/MI. Sampel positif Escherichia coli diperoleh dari 2 ritel modern dan 2 SD. Hasil pengujian Escherichia coli pathogen berdasarkan lokasi di sajikan pada Tabel 3 . 
Tabel 2 Hasil Pengujian Escherechia coli Patogen Berdasarkan Jenis Registrasi

\begin{tabular}{|c|c|c|c|c|c|c|c|c|c|c|c|c|c|}
\hline \multirow{3}{*}{ No } & \multirow{3}{*}{ Jenis Sampel } & \multirow{3}{*}{$\begin{array}{c}\text { Jenis } \\
\text { Registrasi }\end{array}$} & \multirow{3}{*}{$\mathbf{N}$} & \multirow{3}{*}{$\begin{array}{l}\text { Standar } \\
\text { (APM/g) }\end{array}$} & \multirow{3}{*}{$\begin{array}{c}\text { Nilai } \\
\text { APM } \\
\text { Rata- } \\
\text { rata }\end{array}$} & \multirow{2}{*}{\multicolumn{2}{|c|}{$\begin{array}{c}\text { Temuan } \\
\text { Escherichia coli } \\
\text { Metode } \\
\text { Konvensional }\end{array}$}} & \multicolumn{6}{|c|}{ Temuan Escherichia coli Metode Multiplex PCR } \\
\hline & & & & & & & & \multicolumn{2}{|c|}{ ETEC } & \multicolumn{2}{|c|}{ EPEC } & \multicolumn{2}{|c|}{ EHEC } \\
\hline & & & & & & Jumlah & $\begin{array}{c}\text { Persentase } \\
(\%)\end{array}$ & Jumlah & $\begin{array}{c}\text { Persentase } \\
(\%)\end{array}$ & Jumlah & $\begin{array}{c}\text { Persentase } \\
(\%)\end{array}$ & Jumlah & $\begin{array}{c}\text { Persentase } \\
(\%)\end{array}$ \\
\hline 1 & Tepung Terigu & MD & 8 & $<3$ & 0 & 0 & 0 & 0 & 0 & 0 & 0 & 0 & 0 \\
\hline \multirow[t]{2}{*}{2} & \multirow{2}{*}{$\begin{array}{l}\text { Mi basah } \\
\text { mentah }\end{array}$} & P-IRT & 7 & $<3$ & 0 & 0 & 0 & 0 & 0 & 0 & 0 & 0 & 0 \\
\hline & & Curah & 1 & $<3$ & 0 & 0 & 0 & 0 & 0 & 0 & 0 & 0 & 0 \\
\hline 3 & Tahu & P-IRT & 8 & $<3$ & $>1100$ & 5 & 62,5 & 0 & 0 & 0 & 0 & 0 & 0 \\
\hline 4 & Biskuit & $\mathrm{MD}$ & 4 & $<3$ & 0 & 0 & 0 & 0 & 0 & 0 & 0 & 0 & 0 \\
\hline 5 & Keik & P-IRT & 4 & $<3$ & 0 & 0 & 0 & 0 & 0 & 0 & 0 & 0 & 0 \\
\hline 6 & Sosis ayam & MD & 4 & $<3$ & 0 & 0 & 0 & 0 & 0 & 0 & 0 & 0 & 0 \\
\hline 7 & Sosis sapi & MD & 4 & $<3$ & 0 & 0 & 0 & 0 & 0 & 0 & 0 & 0 & 0 \\
\hline 8 & $\begin{array}{l}\text { Dendeng } \\
\text { daging }\end{array}$ & P-IRT & 8 & $<3$ & 0 & 0 & 0 & 0 & 0 & 0 & 0 & 0 & 0 \\
\hline \multirow[t]{2}{*}{9} & \multirow[t]{2}{*}{ Bakso daging } & MD & 4 & $<3$ & 0 & 0 & 0 & 0 & 0 & 0 & 0 & 0 & 0 \\
\hline & & P-IRT/SP & 4 & $<3$ & 0 & 0 & 0 & 0 & 0 & 0 & 0 & 0 & 0 \\
\hline 10 & Bakso ikan & MD & 4 & $<3$ & 0 & 0 & 0 & 0 & 0 & 0 & 0 & 0 & 0 \\
\hline 11 & Otak-otak ikan & $\mathrm{MD}$ & 4 & $<3$ & 0 & 0 & 0 & 0 & 0 & 0 & 0 & 0 & 0 \\
\hline 12 & Agar-agar & PSS & 9 & $<3$ & 0 & 0 & 0 & 0 & 0 & 0 & 0 & 0 & 0 \\
\hline 13 & Es teh & PSS & 9 & $<3$ & 21 & 1 & 11,11 & 0 & 0 & 0 & 0 & 0 & 0 \\
\hline 14 & Es sirup & PSS & 9 & $<3$ & 131 & 2 & 22,22 & 0 & 0 & 0 & 0 & 0 & 0 \\
\hline 15 & Bakso pentol & PSS & 9 & $<3$ & 0 & 0 & 0 & 0 & 0 & 0 & 0 & 0 & 0 \\
\hline
\end{tabular}


Tabel 3 Hasil Pengujian Escherechia coli Patogen Berdasarkan Lokasi

\begin{tabular}{|c|c|c|c|c|c|c|c|c|c|c|c|c|c|}
\hline \multirow{3}{*}{ No } & \multirow{3}{*}{ Jenis Sampel } & \multirow{3}{*}{$\begin{array}{c}\text { Lokasi } \\
\text { Sampling }\end{array}$} & \multirow{3}{*}{$\mathbf{N}$} & \multirow{3}{*}{$\begin{array}{l}\text { Standar } \\
(\mathrm{APM} / \mathrm{g})\end{array}$} & \multirow{3}{*}{$\begin{array}{c}\text { Nilai } \\
\text { APM } \\
\text { Rata- } \\
\text { rata }\end{array}$} & \multirow{2}{*}{\multicolumn{2}{|c|}{$\begin{array}{c}\text { Temuan } \\
\text { Escherichia coli } \\
\text { Metode Konvensional }\end{array}$}} & \multicolumn{6}{|c|}{ Temuan Escherichia coli Metode Multiplex PCR } \\
\hline & & & & & & & & \multicolumn{2}{|c|}{ ETEC } & \multicolumn{2}{|c|}{ EPEC } & \multicolumn{2}{|c|}{ EHEC } \\
\hline & & & & & & Jumlah & $\begin{array}{c}\text { Persentase } \\
(\%)\end{array}$ & Jumlah & $\begin{array}{c}\text { Persentase } \\
(\%)\end{array}$ & Jumlah & $\begin{array}{c}\text { Persentase } \\
(\%)\end{array}$ & Jumlah & $\begin{array}{c}\text { Persentase } \\
(\%)\end{array}$ \\
\hline 1 & $\begin{array}{l}\text { Tepung } \\
\text { Terigu }\end{array}$ & Ritel modern & 8 & $<3$ & 0 & 0 & 0 & & 0 & & 0 & & 0 \\
\hline \multirow[t]{2}{*}{2} & \multirow{2}{*}{$\begin{array}{l}\text { Mi basah } \\
\text { mentah }\end{array}$} & Ritel modern & 7 & $<3$ & 0 & 0 & 0 & & 0 & & 0 & & 0 \\
\hline & & $\begin{array}{c}\text { Pasar } \\
\text { tradisional }\end{array}$ & 1 & $<3$ & 0 & 0 & 0 & & 0 & & 0 & & 0 \\
\hline 3 & Tahu & Ritel modern & 8 & $<3$ & $>1100$ & 5 & 62,5 & & 0 & & 0 & & 0 \\
\hline 4 & Biskuit & Titel modern & 4 & $<3$ & 0 & 0 & 0 & & 0 & & 0 & & 0 \\
\hline \multirow[t]{2}{*}{5} & \multirow[t]{2}{*}{ Keik } & Ritel modern & 1 & $<3$ & 0 & 0 & 0 & & 0 & & 0 & & 0 \\
\hline & & $\begin{array}{c}\text { Pasar } \\
\text { Tradisional }\end{array}$ & 3 & $<3$ & 0 & 0 & 0 & & 0 & & 0 & & 0 \\
\hline 6 & Sosis ayam & $\begin{array}{c}\text { Pasar } \\
\text { tradisional }\end{array}$ & 4 & $<3$ & 0 & 0 & 0 & & 0 & & 0 & & 0 \\
\hline 7 & Sosis sapi & Ritel modern & 4 & $<3$ & 0 & 0 & 0 & & 0 & & 0 & & 0 \\
\hline \multirow[t]{2}{*}{8} & \multirow{2}{*}{$\begin{array}{l}\text { Dendeng } \\
\text { daging }\end{array}$} & Ritel modern & 1 & $<3$ & 0 & 0 & 0 & & 0 & & 0 & & 0 \\
\hline & & $\begin{array}{c}\text { Pasar } \\
\text { tradisional }\end{array}$ & 7 & $<3$ & 0 & 0 & 0 & & 0 & & 0 & & 0 \\
\hline \multirow[t]{2}{*}{9} & \multirow[t]{2}{*}{ Bakso daging } & Ritel modern & 2 & $<3$ & 0 & 0 & 0 & & 0 & & 0 & & 0 \\
\hline & & $\begin{array}{c}\text { Pasar } \\
\text { tradisional }\end{array}$ & 6 & $<3$ & 0 & 0 & 0 & & 0 & & 0 & & 0 \\
\hline 10 & Bakso ikan & $\begin{array}{c}\text { Pasar } \\
\text { tradisional }\end{array}$ & 4 & $<3$ & 0 & 0 & 0 & & 0 & & 0 & & 0 \\
\hline 11 & $\begin{array}{l}\text { Otak-otak } \\
\text { ikan }\end{array}$ & $\begin{array}{c}\text { Pasar } \\
\text { tradisional }\end{array}$ & 4 & $<3$ & 0 & 0 & 0 & & 0 & & 0 & & 0 \\
\hline 12 & Agar-agar & SD/MI & 9 & $<3$ & 0 & 0 & 0 & & 0 & & 0 & & 0 \\
\hline 13 & Es teh & SD/MI & 9 & $<3$ & 21 & 1 & 11,11 & & 0 & & 0 & & 0 \\
\hline 14 & Es sirup & SD/MI & 9 & $<3$ & 131 & 2 & 22,22 & & 0 & & 0 & & 0 \\
\hline 15 & Bakso pentol & SD/MI & 9 & $<3$ & 0 & 0 & 0 & & 0 & & 0 & & 0 \\
\hline
\end{tabular}


Dari hasil penelitian ini didapatkan hasil bahwa sebanyak $62,5 \%$ sampel tahu, $22,22 \%$ sampel es sirup dan $11,11 \%$ sampel es teh positif ditemukan adanya Escherichia coli, tetapi Escherichia coli yang ditemukan pada sampel tersebut tidak pathogen setelah diuji menggunakan multiplex PCR.

Pada sampel tahu, es sirup dan es the masingmasing memiliki nilai indeks rata-rata APM sebesar>1100 APM/g, 131 APM/g dan 21 APM/g, dimana angka tersebut berada di atas ambang batas maksimum cemaran mikroba yang telah ditetapkan dalam Peraturan BPOM RI No. HK.00.06.1.52.4011 tentang penetapan batas maksimum cemaran mikroba dan kimia dalam makanan. Sedangkan pada penelitian Pasalu et al (2013), dari hasil uji Escherichia coli-coliform metode APM didapatkan hasil pada es jeruk dan es buah secara berurutan terdapat Escherichia coli dengan indeks APM secara berurutan, yaitu $23 \mathrm{APM} / 100 \mathrm{ml}$ dan 240 $\mathrm{APM} / 100 \mathrm{~mL}$.

Tahu dengan kandungan protein sekitar $8 \%$ atau lebih dan $a_{w}$ 0,89-0,99, menyebabkan tahu menjadi media yang cocok untuk pertumbuhan mikroba. Tigkat populasi bakteri yang tinggi akan menyebabkan perubahan mutu tahu, karena matabolit yang dihasilkan selama pertumbuhan bakteri. Sumber cemaran bakteri pada tahu dapat melalui bahan baku, yaitu kedelai dan atau air, juga lingkungan produksi dan pekerja. Tanah dan air merupakan habitat bakteri, diantaranya Escherichia coli, Staphylococcus aureus, Bacillus cereus dan bakteri pembentuk spora (Rajkovic et al., 2013; Mailia et al., 2015).Es sirup dan es teh memiliki nilai rata-rata APM yang melebihi ambang batas maksimum cemaran mikroba karena pada kedua sampel menggunakan air yang mungkin tidak dimasak, es batu yang ditambahkan atau peralatan yang terkontaminasi oleh Escherichia coli serta hygiene penjual yang tidak baik.

Penelitian yang sama terhadap es teh yang pernah dilakukan oleh Ritonga et al.(2013), dari 10 sampel es teh yang diperiksa ditemukan bakteri Escherichia coli. Dari hasil uji laboratorium, adanya cemaran Escherichia coli pada sampel es sirup dan es teh dikarenakan air yang digunakan tidak sampai mendidih, karena bakteri Escherichia coli relative peka terhadap panas dan dapat dihilangkan dengan pendidihan hingga $100^{\circ} \mathrm{C}$, terletak pada penyimpanan es teh yang terlalu lama di dispenser, sirup yang disimpan dalam wadah yang kurang bersih serta es batu yang digunakan mengandung Escherichia coli.

Penyakit akibat makanan yang terjadi segera setelah mengkonsumsi pangan, umumnya disebut sebagai keracunan. Pangan dapat menjadi beracun karena telah terkontaminasi oleh bakteri pathogen yang selanjutnya dapat tumbuh dan berkembang biak selama penyimpanan, sehingga bakateri pathogen tersebut mampu memproduksi toksin yang dapat membahayakan manusia. Keracunan pangan oleh bakteri dapat berupa intoksifikasi atau infeksi. Intoksifikasi disebabkan oleh adanya toksin bakteri yang terbentuk di dalam makanan pada saat bakteri bermultiplikasi, sedangkan keracunan pangan berupa infeksi disebabkan oleh masuknya bakteri kedalam tubuh melalui makanan yang terkontaminasi dan tubuh memberikan reaksi terhadap bakteri tersebut (BPOM, 2008; Pasalu, 2013).

Hasil pengujian deteksi Escherichia coli pda sampel tahu, es sirup dan es teh dengan menggunakan media EMBA terdapat mirkoba yang tumbuh dengan ciri-ciri spesifik sebagai Escherichia coli, namun setelah dilanjutkan dengan uji multiplex PCR dari koloni yang tumbuh pada EMBA tersebut tidak ditemukan Escherichia coli pathogen.

Pada penelitian ini terdapat beberapa kelemahan, diantaranya Escherichia coli pada pangan yang diperoleh dari pasar tradisional, ritel modern, dan SD/MI tidak dapat diketahui faktor penyebab, karena tidak dilakukan pengamatan secara prospektif dan terus menerus serta tidak dilakukan uji multiplex PCR untuk Escherichia coli pathogen jenis EIEC dan EAEC. 


\section{KESIMPULAN}

Dari hasil penelitian dapat disimpulkan pada 5 sampel tahu, 2 sampel es sirup dan 1 sampel es teh yang diuji menggunakan metode konvensionalditemukan Escherichia coli ATCC 25922dengan masing-masing nilai index rata-ratasecara berurutan sebesar $>1100$ APM/g, 131 APM/g dan 21 APM/g.Escherichia coli yang ditemukan pada sampel tahu, es sirup dan es teh tidak ada satupun yang pathogen setelah diuji menggunakan multiplex PCR.

\section{DAFTAR PUSTAKA}

Biswas, S., M.A.K. Parves, M. Shafiquzzaman, S. Nahar and M.N. Rahman. 2010. Isolation and Characterization of Escherichia coli in Ready-to-eats Foods Vended in Islamic University Kushtia. J. Biol-Sci. 18 : 99-103.

BPOM. 2008. Pengujian Mikrobiologi Pangan. InfoPOM. 9(2) : 1-9.

BPOM. 2015. Listeria monocytogenes Sebagai Agen Penyebab Keracunan Pangan. InfoPOM. 16 (1) : 3-5.

Djoepri, M.R. 2006. Isolasi dan Identifikasi Mikroba Escherichia coli pada Makanan Sosis dan Nuget. Temu Teknis Nasional Tenaga Fungsional Pertanian. 265-268.

Huang, D.B., Mohanty, Dupont, H.L., Okhuysen, P.C. and Chiang T. 2006. A Review of An Emeging Enteric Pathogen Enteroaggregative Escherichia coli. J. Med-Microbiol. 55 : 1303-1311.

International Standard Organization. 2006. Milk and Milk Product : Detection Enterobacter sakazakii. First Esition. 22964. IDF/RM 210.

Kumar, S.H., Iddya, K., Karunasajar, I. 2002. Molecular. Methods for Rapid and Sorum, H., and Sunde. 2001. Resitance to Antibiotics in the Normal Flora od Animals. Vet Res. 32 : 227-241.

Tannock, G.W. 1995. Normal Microflora An Introduction to Microbes Inhabiting.
Specific detection of Pathogens in Seafood. Aquacult Asia 3. 34-37.

Mailia, R., B. Yudhistira, Y. Pranoto, dan S. Rochdyanto. 2015. Ketahanan Panas Cemaran Mikroba Escherichia coli, Staphylococcus aureus, Bacillus cereus dan Bakteri Pembentuk Spora yang Diisolasi dari Proses Pembuatan Tahu di Sudagaran Yogyakarta. Agritech. 35 (3) : 300-308.

Peraturan BPOM Hk.00.061.1.52.4011. 2009. Penetapan Batas Maksimum Cemaran Mikroba dan Kimia Dalam Makanan.

Perreten, V. 2005. Resistance in the Food Chain in Bacteria From Animals : Relevance to Human Infections, In White D.G., Aleksum M.N., McDemont PF (eds). Frontiers in Antimicrobial Resistance. ASM Press. Washington DC. 446-464 pp.

Rajkovic, A., Kljajic, M., Smigic, N., Devlieghere, F., and Uttendale, M. 2013. Toxin Producing Bacillus cereus Persist in Ready-to-reheat Spagheti Bolognese Mainly in Vegetative State. International Journal of Food Microbiology. 167 : 236-243.

Ritonga, R., I. Marsaulina dan I. Chahaya. 2013. Analisis Escherichia coli dan Higiene Sanitasi pada Minuman Es Teh yang Dijual di Pajak Karona Jamin Ginting, Kec. Medan Baru. FKM. USU.

Siagian, A. 2002. Mikroba Patogen pada Makanan dan Sumber Pencemarannya. USU Digital Library. FKM. Univ. Sumatera Utara. Then Human Body. Chapman and Hall. London. 